\title{
Phosphorylated secretory proteins from rat epididymis and their androgenic control
}

\author{
S. Mongkolsirikieat and M. Chulavatnatol \\ Department of Biochemistry, Faculty of Science, Mahidol University, Rama VI Road, \\ Bangkok 10400, Thailand
}

\begin{abstract}
Summary. Slices of the rat epididymis were incubated with $\left[{ }^{32} \mathrm{P}\right]$ orthophosphate. Analysis of the radioactive proteins in the medium by two-dimensional gel electrophoresis and autoradiography revealed 6-phosphorylated secretory proteins from the epididymis of adult rats: $M_{r}=62000 ; 66000 ; 76000 ; 68000 ; 19000$ and 20000 . Studies of the epididymides of immature and 7-day-castrated adult rats indicated that these phosphorylated secretory proteins were controlled by androgens.
\end{abstract}

\section{Introduction}

Sperm maturation requires proteins secreted from the epididymis (Orgebin-Crist \& Jahad, 1978, 1979) and this has led to intensive investigation of these proteins. In the rat, there are several species of epididymal secretory proteins (Koskimies \& Kormano, 1975; Turner, Plesums \& Cabot, 1979) of which some are glycoproteins (Brooks, 1981a; Jones, Pholpramool, Setchell \& Brown, 1981; Garberi, Fontana \& Blaquier, 1982) and some have been specifically characterized as sialoglycoproteins (Faye, Duguet, Mazzuca \& Bayard, 1980; Toowicharanont \& Chulavatnatol, 1983). Their synthesis and secretion are androgen-dependent (Brooks \& Higgins, 1980; Jones, Brown, von Glos \& Parker, 1980; Brooks, 1981a, b; Kohane, Pineiro \& Blaquier, 1983). There are also differences in the proteins secreted from different regions of the epididymis (Faye et al., 1980; Kohane, Cameo, Pineiro, Garberi \& Blaquier, 1980; Brooks, 1981a; Wong, Tsang \& Lee, 1981). Certain secretory proteins have been shown to bind with maturing spermatozoa (Kohane, Gonzalez-Echeverria, Pineiro \& Blaquier, 1980; Dravland \& Joshi, 1981; Jones \& Brown, 1982; Wong \& Tsang, 1982; Brooks \& Tiver, 1983; Brown, von Glos \& Jones, 1983). The present study shows that some of these secretory proteins are secreted in phosphorylated forms.

\section{Materials and Methods}

Adult albino Fischer rats weighing 250-300 g were used. Castration was performed as described previously (Mongkolsirikieat \& Chulavatnatol, 1983). Immature rats, 21 days old and weighing 20$35 \mathrm{~g}$, were also used.

The epididymides were surgically removed from adult (intact), 7-day castrated and immature rats under ether anaesthesia. The slices of caput or cauda epididymidis were prepared by cutting the organ with a pair of scissors in $150 \mu \mathrm{l}$ Hanks' balanced salt solution, pH 7.4 (HBSS; for composition, see Mongkolsirikieat \& Chulavatnatol, 1983). The tissue slices $(0.35-0.40 \mathrm{~g}$ wet weight) were pooled from 1, 2 or 16 epididymides of adult, castrated or immature rats respectively and transferred into a vial containing $150 \mu \mathrm{l}$ neutralized ${ }^{32} \mathrm{Pi}$ which was prepared as follows. Carrier-free ${ }^{32} \mathrm{Pi}$ in $(120 \mu \mathrm{l}) 0.1 \mathrm{M}-\mathrm{HCl}$ (sp. act. $10 \mathrm{mCi} / \mathrm{ml}$; Radiochemical Centre, Amersham, U.K.) was heated in a boiling water bath for 3-5 min before neutralization with $20 \mu \mathrm{l} 0.3 \mathrm{M}$-Tris$\mathrm{HCl}$ buffer, $\mathrm{pH} 7 \cdot 7$, and $40 \mu \mathrm{l}$ of a solution of 4 times the concentration of HBSS. The final $\mathrm{pH}$ of the 
mixture was $7 \cdot 4$. The incubation of the tissue slices with the radioisotope was carried out in a shaking water bath at $33^{\circ} \mathrm{C}$ for $3 \mathrm{~h}$. At the end of the incubation, $300 \mu \mathrm{l}$ ice-cold HBSS were added to the incubation mixture. Then the tissue slices were collected by centrifugation at $35 \mathrm{~g}$ at room temperature for $5 \mathrm{~min}$. The supernatant fluid was further centrifuged at $800 \mathrm{~g}$ at room temperature for $10 \mathrm{~min}$ to remove the spermatozoa (present in preparations from adult rats only).

The clear supernatant fluid containing $100 \mu \mathrm{g}$ proteins was subjected to 2-dimensional gel electrophoresis. The first dimension was performed under non-denaturing conditions in a $7.5 \%$ polyacrylamide gel (Cameo \& Blaquier, 1976). The appropriate strip from the first dimension was cut and incubated for $30 \mathrm{~min}$ at room temperature in the denaturing buffer which was $65 \mathrm{~mm}$-Tris$\mathrm{HCl}, \mathrm{pH} 6.8$, glycerol and $1 \%$ sodium dodecyl sulphate (SDS), $4 \%$ glycerol and $1 \% \beta$ mercaptoethanol. The gel strip was then positioned on top of an SDS 7-15\% acrylamide gel (15-cm width $\times 10-\mathrm{cm}$ length $\times 0 \cdot 1-\mathrm{cm}$ thickness). One side well contained proteins of known molecular weights and the other contained the supernatant fluid from the incubation. Both were treated with the denaturing buffer before loading. The second dimension electrophoresis was performed as described by Laemmli (1970). After the electrophoresis, the proteins were made visible by staining with $0.2 \%(\mathrm{w} / \mathrm{v})$ Coomassie brillant blue. The gel slab was then dried between two cellophane sheets using a Bio-Rad gel drier (Model 224). Autoradiography was performed by placing the dried gel between two sheets of Kodak X-O-mat X-ray film held within two glass slabs or two intensifying screens (Okamato, JL $8 \times 10$ ). The films were left exposed to the radioactivity for various lengths of time before developing.

To determine the nature of the phosphoryl linkages to proteins, the methanol-fixed gel was treated with $1 \mathrm{M}-\mathrm{NaOH}$ or $1 \mathrm{M}-\mathrm{HCl}$ for $1 \mathrm{~h}$ at room temperature before dye staining and subsequent autoradiography.

To show the secretion of the radioactive proteins from the epididymal tissue slices by pulsechase experiment, the ${ }^{32} \mathrm{Pi}$ incubation of the tissue slices was carried out for only $2 \mathrm{~h}$ (pulse period). After adding the ice-cold HBSS and pelleting the tissue slices by centrifugation, the collected tissue slices were resuspended in HBSS and washed twice by centrifuging through a layer of $3 \%$ Ficoll as described by Mongkolsirikieat \& Chulavatnatol (1983). The washed tissue slices were re-incubated in $300 \mu \mathrm{l} \mathrm{HBSS}$ alone at $33^{\circ} \mathrm{C}$ for $3 \mathrm{~h}$ (chase period). At $1-\mathrm{h}$ intervals during the chase period, an aliquant $(70 \mu \mathrm{l})$ of the incubation mixture was removed and centrifuged at $800 \mathrm{~g}$ for $5 \mathrm{~min}$ to remove the tissue. The trichloroacetic acid (TCA)-insoluble material carrying ${ }^{32} \mathrm{P}$ in the supernatant fluid was determined by TCA paper chromatography and liquid scintillation counting.

\section{Results}

During the incubation, ${ }^{32} \mathrm{Pi}$ was taken up by the tissue slices and converted into $\left[\gamma-{ }^{32} \mathrm{P}\right] \mathrm{ATP}$ as well as other $\left[{ }^{32} \mathrm{P}\right]$ nucleotides. $\left[\gamma-{ }^{32} \mathrm{P}\right] \mathrm{ATP}$ would be used by protein kinases to form radioactive phosphorylated proteins. After the incubation, the tissue slices were separated from the medium, washed and the cytosolic fraction was prepared as described previously (Mongkolsirikieat \& Chulavatnatol, 1983). Using 2-dimensional gel electrophoresis and autoradiography, the cytosolic fraction yielded a very complex pattern consisting of numerous radioactive proteins while the medium showed a simple pattern of fewer radioactive proteins. Therefore the medium, which consisted of secretory proteins, was considered more suitable for further analysis.

\section{Intact adult rats}

When the clear supernatant fluid from the ${ }^{32} \mathrm{Pi}$ incubation medium of the cauda epididymidis of intact adult rats was analysed by 2-dimensional gel electrophoresis, there were several protein spots (Pl. 1, Fig. 1), including one most intensive albumin spot (A) and 5 pre-albumin spots (B-E) as observed by others (Brooks, 1981b; Brown et al., 1983). The autoradiograph of this gel showed 6 


\section{PLATE 1}

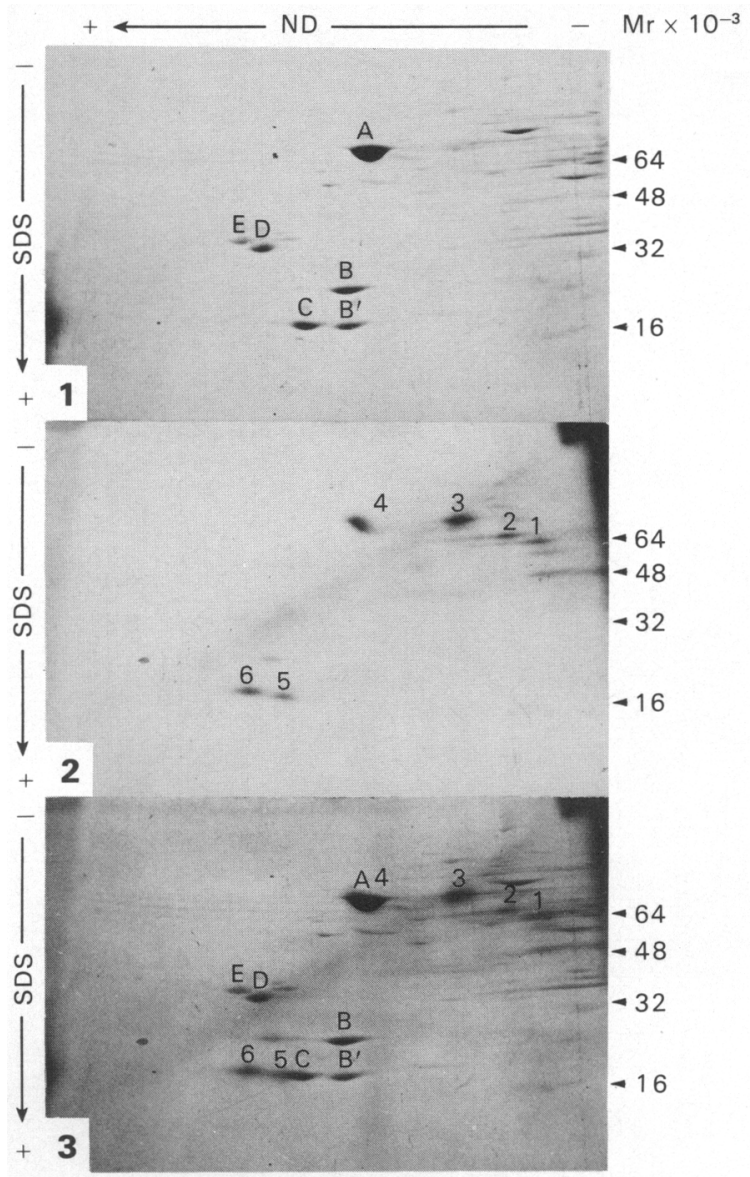

Two-dimensional gel electrophoresis of $100 \mu \mathrm{g}$ secretory proteins from the ${ }^{32} \mathrm{Pi}$-incubated tissue slices of the cauda epididymidis of intact adult rats. The molecular weight markers were cross-linked haemoglobin, tetramer $(64000)$, trimer $(48000)$, dimer $(32000)$ and monomer $(16000)$.

Fig. 1. Protein pattern.

Fig. 2. Autoradiograph after exposure to the gel for 14 days.

Fig. 3. Superimposition of protein pattern onto the autoradiograph. 


\section{PLATE 2}

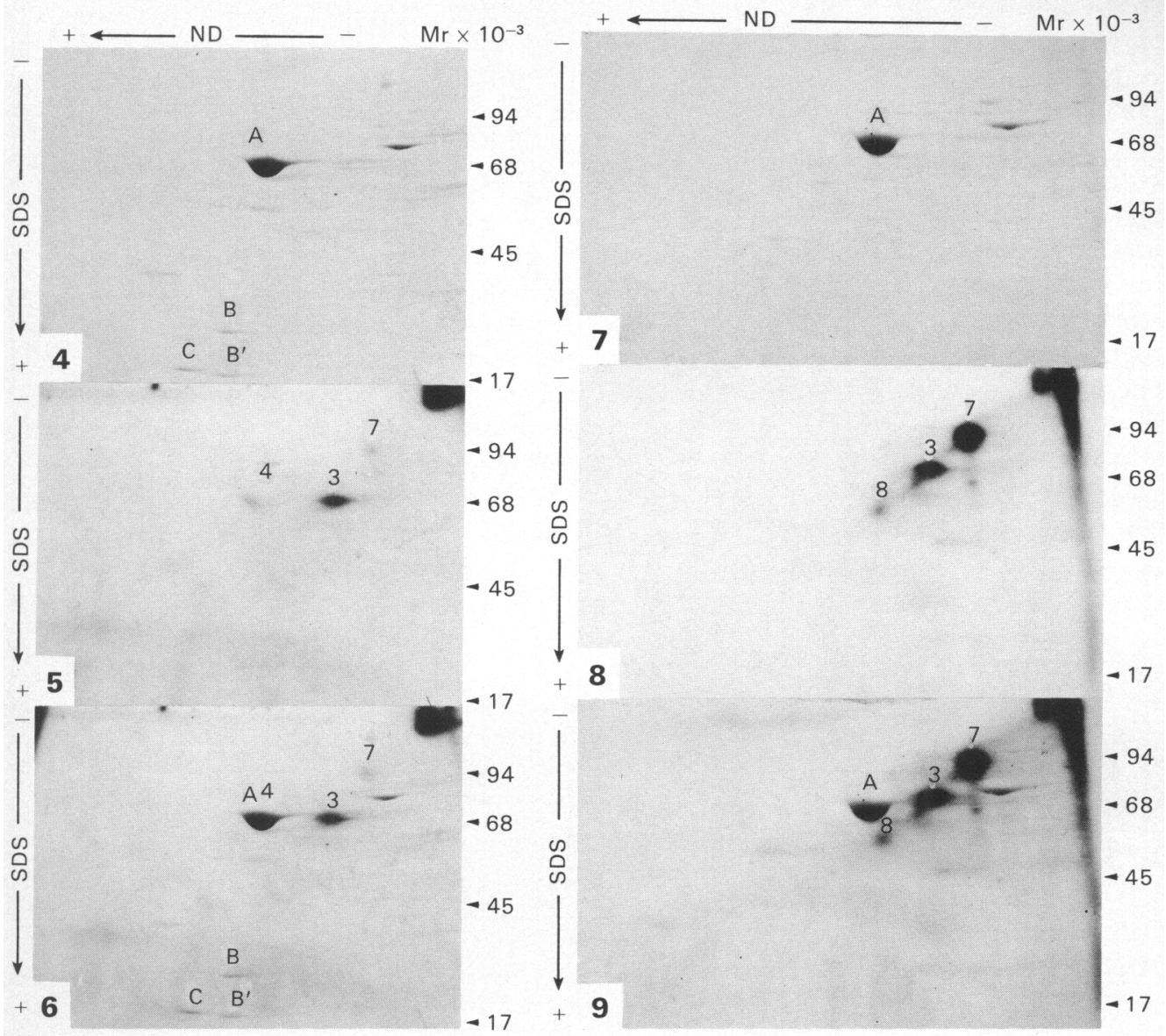

Two-dimensional gel electrophoresis of $100 \mu \mathrm{g}$ secretory proteins from the ${ }^{32} \mathrm{Pi}$-incubated tissue slices of the cauda epididymidis of 7-day-castrated adult rats (Figs 4-6) and immature rats (Figs 7-9). The molecular weight markers were phosphorylase b $(94000)$, bovine serum albumin (68 000), ovalbumin (45000) and myoglobin (17000).

Figs 4 \& 7. Protein pattern.

Figs 5 \& 8. Autoradiograph after exposure to the gel with intensifying screens for 10 days.

Figs 6 \& 9. Superimposition of protein pattern onto the autoradiograph. 
intensive radioactive spots (designated by number 1-6) and several faint spots (Pl. 1, Fig. 2). Upon superimposition of the autoradiograph onto the electrophoretic gel, guided by the edges of the gel and their outline in the film, only radioactive spot 4 fell on part of protein spot $A$ while the other radioactive spots did not coincide with any observable protein spots (Pl. 1, Fig. 3). The molecular weights of the radioactive spots were: (1) 62000 ; (2) 66000 ; (3) 76000 ; (4) 68000 ; (5) 19000 and (6) 20000 . For the fluid from the caput epididymidis of the intact adult rats (data not shown), the protein pattern was exactly the same as in Pl. 1, Fig. 1 except that spot E was missing, and its autoradiograph was identical to that in $\mathrm{Pl}$. 1, Fig. 2.

After treatment with $\mathrm{NaOH}$ or $\mathrm{HCl}$, there was no observable loss of protein spots from the gel. However, the alkali treatment markedly decreased the intensities of the radioactive spots while the acid treatment did not. Pronase treatment of the fluid before electrophoresis also abolished the radioactive spots. These tests suggested that the radioactivity was associated with proteins and that the phosphoryl linkage was alkali-labile.

From the pulse-chase experiment, there was a progressive release of the TCA-insoluble material from the ${ }^{32} \mathrm{Pi}$ incubated tissue slices up to $3 \mathrm{~h}$ (Text-fig. 1). When equal weights of tissue were used, the tissue slices from the cauda epididymidis secreted more radioactive material than did those from the caput region. Electrophoresis of fluid collected after a $2-h$ pulse period and after a 3 -h chase period and subsequent autoradiography revealed identical radioactive band patterns in the two fluid samples.

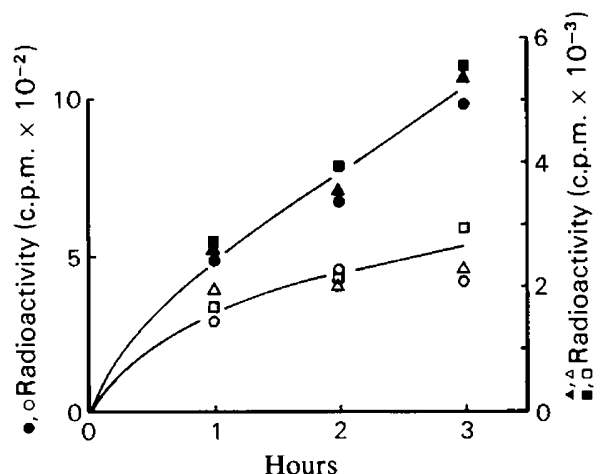

Text-fig. 1. Time course for the release of TCA-insoluble material from ${ }^{32} \mathrm{Pi}$-incubated tissue slices of the caput (open symbols) or cauda (closed symbols) epididymidis of intact adult rats. Three incubations were performed, each used one epididymis represented by $O$ and $\supset, \triangle$ and $\Delta$ and $\square$ and $\square$. Each point was the average of 2 determinations.

\section{Castrated rats}

Initial experiments showed that tissue slices from adult rats, 7 days after castration, incorporated $10-15$ times more ${ }^{32} \mathrm{P}$ into cytosolic proteins than did those from intact rats. However, the former secreted less radioactive proteins into the medium than the latter, and more epididymides from the castrated rats were needed to provide sufficient secretory proteins for further analysis.

As described previously (Cameo \& Blaquier, 1976), androgen withdrawal markedly reduced the prealbumin spots in the protein pattern of the fluid from the cauda epididymidis of adult rats 7 days after castration (Pl. 2, Fig. 4). An autoradiograph of the protein pattern made under the same conditions as Pl. 1, Fig. 2 gave no visible radioactive spot. However, when the autoradiography was performed using intensifying screens to improve the sensitivity of the detection, spot 3 was clearly visible, spot 4 was faint and a new spot (7) was also faint (Pl. 2, Fig. 5). The intensifying screens normally gave a 5 -fold improvement in detecting ${ }^{32} \mathbf{P}$ by autoradiography ( $\mathrm{S}$. Panyim, personal 
communication). By superimposing the autoradiograph onto the gel (Pl. 2, Fig. 6), radioactive spot 4 coincided with part of protein spot A, suggesting that the faint spot should be the same spot 4 observed in Pl. 1, Fig. 1 for intact rats. The molecular weight of radioactive spot 7 was 83000 while those of spots 3 and 4 were 76000 and 68000 as in intact rats.

\section{Immature rats}

For immature rats, the results were similar to those for castrated adult rats. The protein pattern clearly lacked the prealbumin spots B-E (Pl. 2, Fig. 7), and no spots were visible after autoradiography unless intensifying screens were used. With the intensifying screens, radioactive spots 3 and 7 were well detected, together with a new faint spot $8\left(\mathrm{M}_{\mathrm{r}}=52000\right)(\mathrm{Pl}$. 2, Fig. 8). They did not superimpose on any visible protein spots (Pl. 2, Fig. 9).

The findings for caput epididymal fluid from immature rats or castrated rats (data not shown) were identical with those described for the corresponding caudal region.

The data presented (Pl. 1 \& 2, Figs 1-9) were representative of 5 incubations of the tissues from intact adult rats, 3 from castrated and 3 from immature rats.

\section{Discussion}

The present study clearly shows that at least 6 proteins (or glycoproteins) secreted from the epididymal tubules of rats are phosphorylated. That the phosphorylated proteins are derived from the tissue slices and not from the spermatozoa present in the ${ }^{32} \mathrm{Pi}$ incubation mixture is supported by the following observations. Firstly, in the pulse-chase experiment, the ${ }^{32} \mathrm{Pi}$ incubated tissue slices which had been washed free of spermatozoa progressively secreted phosphorylated proteins during the chase period (Text-fig. 1). Secondly, epididymal spermatozoa are known to form the major phosphorylated proteins that are strongly associated with some intracellular structure (Chulavatnatol, Panyim \& Wititsuwannakul, 1982), and they are therefore unlikely to leak out into the medium.

The following circumstantial evidence supports our contention that the phosphorylated proteins in the incubation medium are the result of selective secretion and not of the general leakiness of the tissue slices. Firstly, the pattern of the cytosolic phosphorylated proteins is different from and more complex than that of the medium. Secondly, the tissue slices of the epididymides of the castrated or immature rats incorporated more radioactivity into the cytosolic proteins than did those of intact adult rats but secreted much less radioactive proteins into the medium. However, to show without doubt that the phosphorylated proteins are being secreted it would be necessary to use isolated intact cells or a specific inhibitor of protein phosphorylation and secretion.

The absence of phosphorylated proteins 1,2 and 4-6 and the presence of phosphorylated protein 3 at a much reduced level in androgen-deficient rats suggests that androgen controls the existence of these proteins in the epididymal secretion. Androgen withdrawal is known to prevent the synthesis of epididymal secretory proteins (Brooks, 1981b) and to decrease the activity and to change the isoenzymes of protein kinase (Mongkolsirikieat \& Chulavatnatol, 1983). Both processes may contribute to the observed decrease in the phosphorylated secretory proteins from the androgen-deficient rats. Since it requires a higher sensitivity (using intensifying screens) to detect the radioactive proteins 7 (Pl. 2, Fig. 5; castrated rats) and 7 and 8 (Pl. 2, Fig. 8; immature rats), it is uncertain whether they are secreted exclusively by the androgen-deficient rats or they are also present (as faints spots in Pl. 1, Fig. 2) in the fluid of the intact adult rats. Furthermore, their role cannot yet be established.

Other properties of the 6 androgen-dependent phosphorylated secretory proteins are unknown. By superimposition (Pl. 1, Fig. 3), phosphorylated protein 4 is probably albumin (A), but the identities of others cannot be determined. Phosphorylated secretory proteins reported previously 
include casein (Bingham, Farrell \& Basch, 1972), tooth dentin (Weinstock \& Leblond, 1973), ovalbumin (Henderson, Moir, Fothergill \& Fothergill, 1981), myosin light chain (Wallace \& Bensusan, 1980), ACTH-related peptides (Eipper \& Mains, 1982; Mains \& Eipper, 1983), parathyroid secretory protein (Bhargava, Russell \& Sherwood, 1983) and vitellogenin (Wang \& Williams, 1982). Although the importance of the phosphorylated forms of these secretory proteins remains to be discovered, the phosphorylation appears to occur in the Golgi apparatus (Bingham et al., 1972) before secretion (Wang \& Williams, 1982) and is a post-translational modification of some secretory proteins from several systems. It is tempting to propose that a similar mechanism also operates in the epididymis.

S.M. received a scholarship from the Faculty of Graduate Studies, Mahidol University. We thank Thitika Vajarodaya and Kannika Kaewdee for secretarial assistance.

\section{References}

Bhargava, G., Russell, J. \& Sherwood, L.M. (1983) Phosphorylation of parathyroid secretory protein. Proc. natn. Acad. Sci. U.S.A. 80, 878-881.

Bingham, E.W., Farrell, H.M., Jr \& Basch, J.J. (1972) Phosphorylation of casein. Role of the Golgi apparatus. J. biol. Chem. 247, 8193-8194.

Brooks, D.E. (1981a) Secretion of proteins and glycoproteins by the rat epididymis: regional differences, androgen-dependence, and effects of protease inhibitors, procaine and tunicamycin. Biol. Reprod. 25, 1099-1117.

Brooks, D.E. (1981b) Metabolic activity in the epididymis and its regulation by androgens. Physiol. Rev. 61, 515-555.

Brooks, D.E. \& Higgins, S.J. (1980) Characterization and androgen-dependence of proteins associated with luminal fluid and spermatozoa in the rat epididymis. J. Reprod. Fert. 59, 363-375.

Brooks, D.E. \& Tiver, K. (1983) Localization of epididymal secretory proteins on rat spermatozoa. J. Reprod. Fert. 69, 651-657.

Brown, C.R., von Glos, K.I. \& Jones, R. (1983) Changes in plasma membrane glycoproteins of rat spermatozoa during maturation in the epididymis. J. Cell Biol.96, 256-264.

Cameo, M.S. \& Blaquier, J.A. (1976) Androgen controlled specific proteins in rat epididymis. J. Endocr. 69, 47-55.

Chulavatnatol, M., Panyim, S. \& Wititsuwannakul, D. (1982) Comparison of phosphorylated proteins in intact rat spermatozoa from caput and cauda epididymidis. Biol. Reprod. 26, 197-207.

Dravland, E. \& Joshi, M.S. (1981) Sperm-coating antigens secreted by the epididymis and seminal vesicle of the rat. Biol. Reprod. 25, 649-658.

Eipper, B.A. \& Mains, R.E. (1982) Phosphorylation of pro-ACTH/endorphin-derived peptides. J. biol. Chem. 257, 4907-4915.

Faye, J.C., Duguet, L., Mazzuca, M. \& Bayard, F. (1980) Purification, radioimmunoassay, and immunohistochemical localization of a glycoprotein produced by the rat epididymis. Biol. Reprod. 23, 423-432.

Garberi, J.C., Fontana, J.D. \& Blaquier, J.A. (1982) Carbohydrate composition of specific rat epididymal protein. Int. J. Androl. 5, 619-626.
Henderson, J.Y., Moir, A.J.G., Fothergill, L.S. \& Fothergill, J.E. (1981) Sequences of sixteen phosphoserine peptides from ovalbumins of eight species. Eur. J. Biochem. 114, 439-450.

Jones, R. \& Brown, C.R. (1982) Association of epididymal secretory proteins showing $\alpha$-lactalbumin-like activity with the plasma membrane of rat spermatozoa. Biochem. J. 206, 161-164.

Jones, R., Brown, C.R., von Glos, K.I. \& Parker, M.G. (1980) Hormonal regulation of protein synthesis in rat epididymis. Characterization of androgen-dependent and testicular fluid-dependent proteins. Biochem. J. 188, 667-676.

Jones, R., Pholpramool, C., Setchell, B.P. \& Brown, C.R. (1981) Labelling of membrane glycoproteins in rat spermatozoa collected from different regions of the epididymis. Biochem. J. 200, 457-460.

Kohane, A.C., Cameo, M.S., Pineiro, L., Garberi, J.C. \& Blaquier, J.A. (1980) Distribution and site of production of specific proteins in the rat epididymis. Biol. Reprod. 23, 181-187.

Kohane, A.C., Gonzalez-Echeverria, F.M.C., Pineiro, L. \& Blaquier, J.A. (1980) Interaction of proteins of epididymal origin with spermatozoa. Biol. Reprod. 23, 737-742.

Kohane, A.C., Pineiro, L. \& Blaquier, J.A. (1983) Androgen-controlled synthesis of specific protein in the rat epididymis. Endocrinology 112, 1590-1596.

Koskimies, A.I. \& Kormano, M. (1975) Proteins in fluids from different segments of the rat epididymis. $J$. Reprod. Fert. 43, 345-348.

Laemmli, U.K. (1970) Cleavage of structural proteins during assembly of head bacteriophage- $\mathrm{T}_{4}$. Nature, Lond. 227, 680-685.

Mains, R.E. \& Eipper, B.A. (1983) Phosphorylation of rat and human adrenocorticotropin-related peptides: physiological regulation and studies of the secretion. Endocrinology 112, 1986-1995.

Mongkolsirikieat, S. \& Chulavatnatol, M. (1983) Androgenic control of the cyclic AMP-dependent protein kinase isoenzymes of the rat epididymis. J. Reprod. Fert. 68, 401-405.

Orgebin-Crist, M.-C. \& Jahad, N. (1978) The maturation of rabbit epididymal spermatozoa in organ culture: inhibition by anti-androgen and inhibitors of ribo- 
nucleic acid and protein synthesis. Endocrinology 103, $46-53$.

Orgebin-Crist, M.-C. \& Jahad, N. (1979) The maturation of rabbit epididymal spermatozoa in organ culture: stimulation by epididymal cytoplasmic extracts. Biol. Reprod. 21, 511-515.

Toowicharanont, P. \& Chulavatnatol, M. (1983) Characterization of sialoglycoproteins of rat epididymal fluid and spermatozoa by periodate-tritiated borohydride. J. Reprod. Fert. 67, 133-141.

Turner, T.T., Plesums, J.L. \& Cabot, C.L. (1979) Luminal fluid proteins of the male rat reproductive tract. Biol. Reprod. 21, 883-890.

Wallace, C.W. \& Bensusan, H.B. (1980) Protein phosphorylation in platelets stimulated by immobilized thrombin at $37^{\circ} \mathrm{C}$ and $4^{\circ} \mathrm{C}$. J. biol. Chem. 255, 1932-1937.
Wang, S.Y. \& Williams, D.L. (1982) Biosynthesis of the vitellogenins. Identification and characterization of nonphosphorylated precursors to avian vitellogenin I and vitellogenin II. J. biol. Chem. 257, 3837-3846.

Weinstock, M. \& Leblond, C.P. (1973) Radioautographic visualization of the deposition of a phosphoprotein at the mineralization front in the dentin of the rat incisor. J. Cell Biol. 56, 838-845.

Wong, P.Y.D. \& Tsang, A.Y.F. (1982) Studies in the binding of a $32 \mathrm{~K}$ rat epididymal protein to rat epididymal spermatozoa. Biol. Reprod. 27, 12391246.

Wong, P.Y.D., Tsang, A.Y.F. \& Lee, W.M. (1981) Origin of the luminal fluid proteins of the rat epididymis. Int. J. Androl. 4, 331-341.

Received 14 February 1984 